\title{
Migrációs regionális profilok vizsgálata Magyarországon, nagymintás adatbázison
}

\author{
Analysis of regional emigration profiles in Hungary \\ based on a large sample
}

\author{
SZILÁGYI ROLAND, VARGA BEATRIX, \\ SISKÁNÉ SZILASI BEÁTA
}

SZILÁGYI Roland: intézetigazgató egyetemi docens, Miskolci Egyetem, Gazdaságtudományi Kar, Gazdaságelméleti és Módszertani Intézet; 3515 Miskolc-Egyetemváros; strolsz@uni-miskolc.hu

VARGA Beatrix: tanszékvezető egyetemi docens, Miskolci Egyetem, Gazdaságtudományi Kar, Gazdaságelméleti és Módszertani Intézet; 3515 Miskolc-Egyetemváros; stbea@uni-miskolc.hu

SISKÁNÉ SZILASI Beáta: tanszékvezető egyetemi docens, Miskolci Egyetem, Műszaki Földtudományi Kar, Földrajz-Geoinformatika Intézet; 3515 Miskolc-Egyetemváros; ecobea@uni-miskolc.hu

KULCSSZAVAK: kivándorlás; migrációs profil; nemzetközi összehasonlítás; regionális egyenlötlenségek

ABSZTRAKT: Kutatásunkban - 2013 és 2016 között közel 6000 fö megkérdezésén alapuló kérdőíves adatgyűjtéssel - válaszokat kerestünk arra a kérdésre, hogy vajon előrejelezhetö-e a lakosság migrációs szándéka. Milyen tényezők befolyásolják azt a döntést, hogy valaki el szeretné hagyni az országot - függetlenül attól, hogy kényszerű, kényelmi, praktikus vagy érzelmi okokból teszi azt. Meg lehet-e mondani, hogy milyen tulajdonságokkal rendelkeznek azok az emberek, akik inkább hajlamosak a kivándorlásra, és mi jellemzi azokat, akik lokálpatrióta érzelmeik miatt nem válnak emigránssá.

Tanulmányunk első részében áttekintjük a 20. és 21. századi magyarországi kivándorlási hullámok kiváltó okait, az emigránsok társadalmi helyzetét, demográfiai jellemzőit, a kibocsátó területeket és a célországokat. A történeti áttekintés célja, hogy a napjainkban vándorbotot fogók és a korábbi exodusok résztvevői közötti hasonlóságokat, illetve különbözőségeket feltárjuk. Megkíséreljük meghatározni, hogy objektív és szubjektív tulajdonságok mennyiben járulnak hozzá ahhoz, hogy valaki külföldre készüljön hosszabb vagy rövidebb időre, illetve mennyivel nagyobb az esélye az itthon maradásnak. A vizsgált tényezők alapján bemutatjuk a régiók közötti különbségeket, valamint azt, hogy a heterogén földrajzi, gazdasági, demográfiai tulajdonságokkal rendelkező lakosok kivándorlási hajlandósága milyen eltéréseket mutat.

A fenti kérdések megválaszolása nem egyszerű. Nemcsak azért, mert összetettségüknél és társadalmi jellegüknél fogva sem a szándék, sem az azt befolyásoló tényezők nem mérhetők egzakt módon, de azért sem, mert a megfelelő módszertan megválasztása is számos további kérdést vet fel. 
Roland SZILÁGYI: associate professor, head of institute, Institute of Economic Theory and Methodology, Faculty of Economics, University of Miskolc; H-3515 Miskolc-Egyetemváros, Hungary; strolsz@uni-miskolc.hu

Beatrix VARGA: associate professor, head of department, Institute of Economic Theory and Methodology, Faculty of Economics, University of Miskolc; H-3515 Miskolc-Egyetemváros, Hungary; stbea@uni-miskolc.hu

Beáta SISKÁNÉ SZILASI: associate professor, head of department, Institute of Geography and Geoinformatics, Faculty of Earth Science and Engineering, University of Miskolc; H-3515 MiskolcEgyetemváros, Hungary; ecobea@uni-miskolc.hu

KEYWORDS: emigration; emigration profile; international comparison; regional inequalities

ABSTRACT: With this research, we aim to answer whether it is possible to predict the population's migration intentions and whether the different regions vary in migration potential. We also ask what kind of factors influence one's determination to leave the country regardless of the fact that it is carried out by force, out of convenience, or for practical or emotional reasons. Can it be determined what characteristics people possess who tend to emigrate? In order to answer these questions, we processed survey information based on interviews with almost 6000 people (age 18-60) between 2013 and 2016.

In the first part of our study, we review the root causes of Hungarian emigration waves during the 20th and 21st centuries as part of which we analyze emigrants' social status, their demographic features, issuing territories and target countries. The aim of the historical overview is to highlight similarities and differences between former exodus participants and today's emigrants.

Addressing the research questions is hard because of their complexity and because it is not possible to measure the contributing factors' social character (either the intention or the influencing factors) in an exact way. Furthermore, methodology raises additional questions. Perhaps this is the reason why the majority of migration studies are limited to the descriptive analysis of the demographic and economic characteristics of the registered emigrants compared to the statistical features of the domestic population. For the same reason, most of these studies fail to estimate and predict the probability of emigration and its changes.

In our study, we use logistic regression function to determine how certain subjective and objective factors (happiness, satisfaction, knowledge, employment, economical, educational background) contribute to the fact that one tends to move abroad for a shorter or longer period of time. Based on this we discuss whether there are differences between the regions with differing geographic, economic and demographic characteristics.

\section{Bevezetés}

A vándorlók mindenütt és mindenkor két ok miatt ragadnak vándorbotot: vagy az életminőségük javításának érdekében vállalják a nem kis traumával járó lakóhely-változtatást, vagy pedig kényszerítik őket otthonuk elhagyására. A rossz életminőség leggyakrabban a nehéz anyagi helyzetet, a kedvezőtlen életkörülményeket jelenti. Politikai, etnikai, vallási alapú üldöztetéssel, háborús krízissel is gyakran találkozhatunk a migrációt kiváltó okok között. Vándorlásra ösztönző motiváció lehet még a jobb egészségügyi ellátás reménye, a tanulás kedvezőbb feltételeinek igénybevétele és a rokoni-etnikai kapcsolatok megerősítésének vágya. Magyarország történelmében a vándorlá- 
sokat kiváltó - korábban említett - valamennyi ok előfordult. Kutatásunkban arra kerestük a választ, hogy milyen mértékủ területi különbségek mutathatók ki az emigrációs okok között.

A vándorlók demográfiai tulajdonságaik alapján jellemezhetőek. Fontos információ az elemzések szempontjából a vándorlók kora, neme, családi állapota, iskolai végzettsége, illetve az a tény, hogy a vándorlók egyénileg vagy csoportosan indulnak „szerencsét próbálni”. A vándorlók jellemzően fiatalabbak az otthon maradt népességnél és alulreprezentált körükben a kisgyermekek aránya. Ennek következtében a migráció a kibocsátó területek öregedésével, a befogadó területek fiatalodásával jár együtt. Ennek a - kibocsátó terület makrogazdasági folyamatai szempontjából kedvezőtlen - következménynek az ellensúlyozására nyilvánvaló lépés lehet a kivándorlás intenzitásának csökkentése.

Az új környezetbe való beilleszkedés annál könnyebben valósul meg, minél felkészültebb a migráns. Az integrálódási folyamatot befolyásolja, hogy a bevándorló beszél-e az új ország nyelvén, van-e piacképes szaktudása, ismeri-e az új haza lakosságának szokásait, el tudja-e fogadni írott és íratlan törvényeit, tisztában van-e a kulturális különbségekkel. Az emigránsok és a kivándorlást még csak tervezők körében végzett felmérések új lehetőséget teremthetnek a migrációs folyamatok, szándékok és indítékok, térségi sajátosságok megismerésében (Gödri, Feleky 2013; Sik, Szeitl 2016).

\section{A magyarországi kivándorlások rövid története}

\section{Emigráció az első világháború előtt}

A korábbi évszázadokban Magyarország migrációs szempontból általában befogadó országnak volt tekinthető. Fordulatot a 19. század vége hozott, amikor tömegek hagyták el az óhazát. A magyarországi emigráció része volt az európai kivándorlási hullámnak, a földnélküliség, a mostoha életkörülmények, a munkanélküliség tömegeket késztetett hazájuk elhagyására.

Magyarország vármegyéiből - a kikötői regisztrációk adatai szerint - 1900 és 1913 között közel másfél millióan érkeztek Észak-Amerikába. A jelentős mértékủ visszavándorlás és a többszöri oda-vissza utazás a kivándorlók tényleges számát valamelyest csökkentette. Az emigránsok többsége az északkeleti vármegyékből származott. Az országot elhagyók között igen nagy számban volt kilátástalan gazdasági és bizonytalan politikai környezetben élő felvidéki, szlovák és rutén lakosság, a kivándorlóknak csupán 30\%-a volt magyar nemzetiségü. A Magyarország területéről kivándorlók túlnyomó többsége föld nélküli paraszt volt (KSH 2011). 


\section{Emigráció a két világháború között és a második világháborút követően}

A két világháború közötti időszakban a kivándorlás minimálisra csökkent, a kivándorlók és a bevándorlók száma közel azonos nagyságú volt. Az Egyesült Államok korlátozó intézkedései következtében Kanada, Argentína, Brazília és Ausztrália lettek az egyre népszerübb célországok. Módosult a kivándorlók társadalmi helyzete is, az agrárnépesség mellett egyre több ipari munkás, kereskedő és értelmiségi hagyta el Magyarországot.

A 20. század tömegeket érintő európai migrációjának újabb szakasza szorosan összefügg a nácizmussal, a holokauszttal és a nacionalizmussal. A 2. világháború alatti és utáni években tömegek menekülése és kényszerkitelepítése jellemezte egész Közép- és Kelet-Európát. Durva becslések szerint 1945 és 1950 között 15,4 millió ember hagyta el hazáját a térségben.

Ebben az időszakban elsősorban politikai és ideológiai okok miatt több tízezren menekültek el Magyarországról. A kollektív büntetés egyik formájaként a 1946 és 1949 között egyes források szerint 170-185 ezer (Illés, Hablicsek 1996; Valuch 2005), míg más források szerint 225-280 ezer (KSH 2011) német nemzetiségü magyar állampolgárt utasítottak ki Magyarországról.

A háború után a holokausztot túlélő zsidóság anyagilag kifosztva, régi gazdasági súlyát elveszítve tekintett a jövőbe, és sokan közülük is a kivándorlást választották. Ausztria és Németország hontalan táboraiban 1945-1948 között megközelítőleg 25 ezer magyarországi zsidót regisztráltak (Endrei 2004).

\section{Migráció a 20. század második felében}

1951-ben a genfi egyezmény hatására Európában befejeződtek a kikényszerített vándormozgalmak. Az országhatárt átlépő migráció Magyarországon évekre megszünt, ugyanis a nyugati határon megépült a szinte átjárhatatlan vasfüggöny (de a szomszédos szocialista országok közötti migráció is lehetetlenné vált).

Csak 1956 októbere ütött rést átmenetileg a hermetikus határzáron, ami a forradalmat követő hetekben újabb tömeges kivándorlási lavinát indított el. Az 1956-os forradalom és szabadságharc leverését követően a Magyarországról elmenekültek összlétszáma - a hivatalos osztrák és jugoszláv jelentések szerint - 193885 fö volt (KSH 1957). Ez a magyar emigráció történetében ez idáig az időegységre jutó legmagasabb kivándorlási érték volt, amely az akkori lakosság közel 2\%-át tette ki, és meghaladta két (akkori) év teljes természetes szaporulatát. Az emigrálók több mint fele 25 évesnél fiatalabb volt, az ország 15-24 éves korú lakosságának több mint 4\%-a vándorolt ki. A külföldre távozottak közel egyharmada a 25-39 éves korosztályhoz tartozott. A kivándorlók között kétszer annyian voltak a férfiak, mint a nők. Különösen sokan éltek az emigrálás lehetőségével a katonaköteles kor előtt álló 19-20 évesek körében. Ennek a társadalmi csoportnak 10\%-a választott új hazát. A forradalmat követő emigráció- 
ban részt vevők több mint fele budapesti lakos volt, és nagy arányban menekültek el az osztrák határhoz közel eső helységekből is. Az alföldi és tiszántúli területek érintettsége volt a legalacsonyabb.

A forradalom leverése után tapasztalt tömeges kivándorlás kedvezőtlenül érintette Magyarország népességének nem és kor szerinti összetételét is. Mivel túlnyomó többségben fiatalok távoztak az országból és fiatalok voltak a harcokban elesett áldozatok is, a 15-25 évesek között volt legszembetűnőbb a nőtöbblet növekedése. Míg 1955-ben a 15-19 éves korcsoportot férfitöbblet jellemezte, addig 1957-ben már nőtöbbletet mutattak az adatok. Ebben a fiatal korcsoportban a feminitási arány (az ezer férfira jutó nők száma) egy év alatt - elsősorban a migrációnak tulajdoníthatóan - 990-ről 1025-re növekedett. A 20-24 éveseknél 1000-ről 1040-re nőtt a feminitási arány.

1957-től hosszú évtizedekre megint szigorú ellenőrzés alá kerültek a határok. 1957 és 1990 között a magyarországi emigráció minimálisra csökkent, és évente csupán néhány ezren hagyták el az országot.

1. táblázat: A 20. század magyarországi kivándorlási hullámainak jellemzői Migration waves in Hungary during the 20th century

\begin{tabular}{|c|c|c|c|c|}
\hline Megnevezés & $\begin{array}{l}\text { Az 1. világháború } \\
\text { előtt (1900-1913) }\end{array}$ & $\begin{array}{l}\text { A 2. világháború } \\
\text { alatt és után (1945- } \\
\text { 1951) }\end{array}$ & $\begin{array}{c}\text { Az 1956.évi } \\
\text { forradalom után } \\
(1956-1957)\end{array}$ & Az 1990-es években \\
\hline $\begin{array}{l}\text { A főbb kibocsátó } \\
\text { területek }\end{array}$ & $\begin{array}{l}\text { Északkeleti } \\
\text { vármegyék }\end{array}$ & $\begin{array}{l}\text { Dél-Alföld, Dél- } \\
\text { Dunántúl régiói }\end{array}$ & $\begin{array}{l}\text { Budapest, } \\
\text { dunántúli régiók }\end{array}$ & $\begin{array}{l}\text { Budapest, a } \\
\text { szocialista ipar } \\
\text { városai }\end{array}$ \\
\hline $\begin{array}{l}\text { A legfontosabb } \\
\text { célországok }\end{array}$ & Egyesült Államok & $\begin{array}{l}\text { Németország, } \\
\text { Izrael, Észak- } \\
\text { Amerika, } \\
\text { Ausztrália }\end{array}$ & $\begin{array}{l}\text { Észak-Amerika, } \\
\text { Nyugat-Európa }\end{array}$ & $\begin{array}{l}\text { Németország, } \\
\text { Ausztria }\end{array}$ \\
\hline $\begin{array}{l}\text { A kivándorlók } \\
\text { tipikus társadalmi } \\
\text { helyzete }\end{array}$ & $\begin{array}{l}\text { Nincstelen } \\
\text { mezőgazdasági } \\
\text { munkások }\end{array}$ & $\begin{array}{l}\text { Magasan } \\
\text { képzettek, } \\
\text { kisebbséghez } \\
\text { tartozók (németek, } \\
\text { szlovákok), zsidók, } \\
\text { katonatisztek, az } \\
\text { arisztokrácia tagjai }\end{array}$ & $\begin{array}{l}\text { Egyetemi } \\
\text { hallgatók, } \\
\text { szakmunkások, } \\
\text { mérnökök, } \\
\text { orvosok }\end{array}$ & $\begin{array}{l}\text { Magasan } \\
\text { képzettek, } \\
\text { munkanélküliek, } \\
\text { felső } \\
\text { középosztálybeliek }\end{array}$ \\
\hline $\begin{array}{l}\text { A kivándorlók nem } \\
\text { szerinti összetétele }\end{array}$ & $\begin{array}{l}\text { Eleinte markáns } \\
\text { férfitöbblet, majd } \\
\text { egyre több nő }\end{array}$ & $\begin{array}{l}\text { A nemek aránya } \\
\text { megközelítőleg } \\
\text { kiegyenlített }\end{array}$ & $\begin{array}{l}\text { Kétharmada férfi, } \\
\text { egyharmada nő }\end{array}$ & Férfitöbblet \\
\hline $\begin{array}{l}\text { A kivándorlás föbb } \\
\text { okai }\end{array}$ & $\begin{array}{l}\text { Kilátástalan } \\
\text { gazdasági helyzet, } \\
\text { rossz } \\
\text { életkörülmények }\end{array}$ & $\begin{array}{l}\text { Politikai üldözés, } \\
\text { kényszerủ } \\
\text { kitelepítések }\end{array}$ & Politikai üldözés & $\begin{array}{l}\text { Jövedelemszerzés, } \\
\text { tanulási cél }\end{array}$ \\
\hline $\begin{array}{l}\text { A kivándorlók kor } \\
\text { szerinti összetétele }\end{array}$ & $\begin{array}{l}\text { Fiatal } \\
\text { korcsoportok }\end{array}$ & $\begin{array}{l}\text { Valamennyi } \\
\text { korosztály érintett }\end{array}$ & $\begin{array}{l}\text { Rendkívül fiatal } \\
\text { korcsoportok }\end{array}$ & $\begin{array}{l}\text { Fiatal } \\
\text { korcsoportok }\end{array}$ \\
\hline
\end{tabular}


A ki- és bevándorlásról szóló, 1989. évi XXIX. törvény hatálybalépését követően a magyar állampolgárok alanyi jogon utazhatnak külföldre. Annak ellenére, hogy a rendszerváltozással szabadon átjárhatóvá váltak a határok, az elvándorlók száma nem növekedett meg drasztikusan az 1990-es években. A kivándorlók között felülreprezentáltak voltak a magasan képzett, nyelvtudással rendelkező fiatalok, akik vagy a jobb megélhetés reményében, vagy a munkanélkülivé válás veszélye elől menekülve fogtak vándorbotot (1. táblázat).

\section{Emigráció a 21. század elején}

2004. május 1-jén Magyarország az Európai Unió tagja lett. A csatlakozás várva várt pillanatával a migráció új lehetőségeinek kapui is kitárultak. Az Egyesült Királyság, Írország, Svédország azonnal megnyitotta munkaerőpiacát Magyarország állampolgárai számára. A többi régi tagország csak fokozatosan biztosította a szabad munkavállalást, legutoljára 2011-ben Németország és Ausztria. Valószínűleg ennek a lépcsőzetes sorompónyitásnak is köszönhető, hogy a munkavállalási engedély eltörlése csak 2007-től érezteti elszívó hatását. A 2008-2009-es pénzügyi és gazdasági világválságnak is nyilvánvalóan volt szerepe a kivándorlás intenzitásának növekedésében.

2007 óta a Nyugat-Európába vándorló és az ott élő magyarok száma folyamatos növekedést mutat. A régi EU-tagországok elsősorban a vendéglátás, az idegenforgalom és az építőipar területén kínálnak álláslehetőségeket a keleteurópai szakmunkásoknak, a felsőfokú végzettségűek közül pedig az egészség-

2. táblázat: A magyarországi elvándorlók jellemzői az EU-hoz való csatlakozás után Characteristics of Hungarian emigrants after the $2004 \mathrm{EU}$ accession

\begin{tabular}{ll}
\hline A legfontosabb célországok & $\begin{array}{l}\text { Németország, Egyesült Királyság, Ausztria, Írország, Hollandia, } \\
\text { Svédország. }\end{array}$ \\
\hline $\begin{array}{l}\text { A kivándorlók tipikus társadalmi } \\
\text { helyzete }\end{array}$ & $\begin{array}{l}\text { Az átlagosnál képzettebb csoport, többségük hajadon vagy } \\
\text { nőtlen. Egészségügyi dolgozók, mérnökök, informatikusok, } \\
\text { szakácsok, felszolgálók, építőipari munkások nagyobb } \\
\text { arányban. }\end{array}$ \\
\hline A kivándorlók nem szerinti & A kivándorlókat összességében férfitöbblet jellemezte, de \\
összetétele & jelentős eltérések mutatkoznak az országok között: \\
& Németországba, az Egyesült Királyságba, a skandináv \\
& országokba vándorlók esetében férfitöbblet mutatkozott, \\
& Olaszországba nőtöbblet volt a jellemző. \\
\hline A kivándorlás főbb oka & Munkavállalás, jövedelemszerzés. \\
\hline A kivándorlók kor szerinti & Fiatal korstruktúra valamennyi befogadó országban; különösen \\
összetétele & magas a fiatal korcsoportok aránya az új célországokban, \\
& Hollandiában, Írországban, Dániában. \\
\hline
\end{tabular}

Forrás: saját szerkesztés Gödri (2015) alapján. 
ügyi dolgozók, a mérnökök és az informatikusok a legkeresettebbek (Földházi 2011). Érthető módon az országot elhagyók között felülreprezentáltak azok, akik a beilleszkedésüket megkönnyítő kulturális és képzettségi tőkével rendelkeztek (2. táblázat).

A nemzetközi vándorlás vizsgálatát megnehezíti az a tény, hogy a migráció számbavétele rendkívül bonyolult és bizonytalan (Ivanyos, Sándorné Kriszt 2017). Gyakran szembesülünk azzal, hogy a kibocsátó és befogadó országok hivatalos adatai jelentősen különböznek egymástól. A tapasztalatok azt mutatják, hogy a magyar hivatalos adatok, amelyek elsősorban az emigráns bejelentési kötelezettségén alapulnak, lényegesen alacsonyabb kivándorlásról tájékoztatnak, mint a befogadó országok tükörstatisztikái. Ezért a migrációs folyamatok pontosabb megismeréséhez elengedhetetlenül szükségesek a különböző empirikus, mintavételeken alapuló kutatások, felmérések.

\section{Adatbázis és módszertan}

A migrációval, illetve az elvándorlási szándékkal, az elvándorlás okaival, motivációjával foglalkozó tanulmányok nagy része az elvándorlásban részt vettek demográfiai és gazdasági jellemzőinek elemzésére korlátozódik (összevetve az itthon maradottakkal). Ezek az elemzések nem foglalkoznak a kivándorlás esélyével, valamint a kivándorlási valószínűség eltérésének becslésével a lakosság különböző csoportjaiban. A magyarországi kivándorlási szándék felméréséhez kérdőíves vizsgálatot végeztünk, közel 6000 főt kérdeztünk meg a megyeszékhelyeken és nagyobb városokban (Molnár et al. 2015). Véletlenen alapuló, nem valószínűségi mintavételezést alkalmaztunk. A mintavételezés helyszíneit többlépcsős valószínűségi mintavételezéssel választottuk ki, ahol csak a nagyobb városok kerültek a mintavételi keretbe. A megkérdezett célcsoport a 18-60 év közötti korosztály, az átlagéletkor a megkérdezettek körében 33,3 év volt.

A lekérdezésekre 20 nagyvárosban került sor, de mivel nem kizárólag helyi lakosok válaszolhattak, így végeredményben az ország több mint 600 településéről sikerült megszólítanunk válaszadókat (például a Budapesten megkérdezettek között minden megyéből voltak válaszadók). Az adatbázis nem elégíti ki ugyan a reprezentativitás követelményeit, de területi megoszlása hasonlít az országos arányokhoz abból a szempontból, hogy a válaszadók közel kétharmada élt a felvétel idején nagyvárosokban. A válaszadók egyharmada nem a megkérdezés helyén élt, hanem kisebb településeken.

A felmérés válaszainak rögzítése és elsődleges elemzése során ki kellett szürnünk a válaszadók egy részét, például azokat, akik az anonimitás garanciája mellett sem adták meg lakóhelyüket, vagy félreérthető, nem releváns válaszokat adtak. A válaszadói szintű adattisztítás mellett néhány válasz tisztítására is sor került, mivel voltak olyan kérdések, amelyekre a válaszadók rendkívül sok- 
1. ábra: A vizsgált minta és a teljes 18-60 éves korosztály regionális megoszlása (2015) Regional distribution of the sample and the 18-60 years old population (2015)

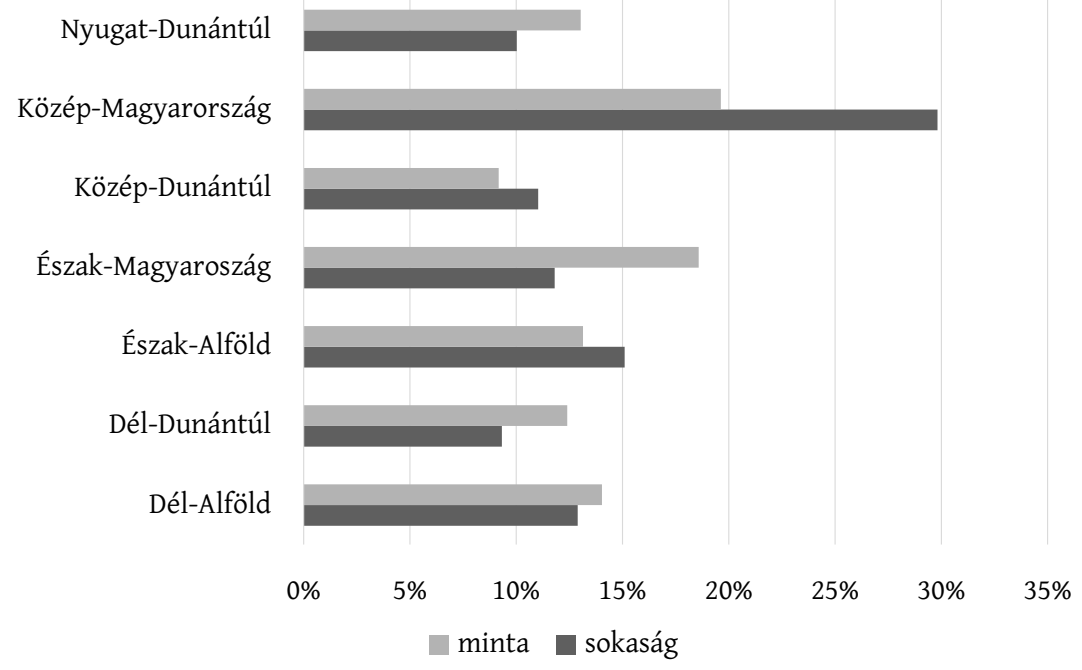

Forrás: saját számítás a KSH adatai alapján.

féle és igen egyedi válaszokat adtak, ellehetetlenítve ezzel a változó számszerüsítését. Îgy végeredményben egy 5493 egyedet tartalmazó adatbázist hoztunk létre, amely méreténél fogva lehetővé teszi területi elemzéseket, illetve a kivándorlók közötti különbségek bemutatását.

Az adattisztítást követően a változók újraskálázását és számos esetben skálatranszformációját hajtottuk végre annak érdekében, hogy az adatelemzési módszerek által megkívánt változókhoz jussunk. Hipotézisünk szerint a kiutazást tervező (de valószínűleg hasonlóképpen az itthon maradni szándékozó) lakosság döntéseit nem kizárólag az egy-egy egyént érintő célok és elgondolások, a vonzó és taszító tényezők befolyásolják, hanem léteznek általános, több embert vagy réteget is együttesen érintő motivációk. Ebből következően a kivándorlók osztályozhatók, tehát rendelkeznek olyan közös jellemzőkkel, melyek alapján többé-kevésbé homogén csoportokat alkotnak. Meg kellett tehát találnunk azokat a tényezőket az adatbázisban, amelyek potenciálisan hatást gyakorolnak a kiutazási szándékra (Sándorné Kriszt 1997). Ennek érdekében logisztikus regressziót alkalmaztunk. Az eredményváltozó a „Tervezi-e a közeljövőben, hogy külföldre megy munkavállalás céljából?” kérdésre adott válaszokból áll. A válaszadók három lehetőség közül választhattak: „,nem tervezi” „gondolkozik rajta”, ,igen, készül kimenni”. Az elemzés kezdetén diszkriminanciafüggvények becslésével próbálkoztunk, hogy megtaláljuk a kiutazási szándékot befolyásoló változóknak azt a lineáris kombinációját, amely a szándékot vagy annak határozottságát legjobban meghatározza. Az elemzési eredmények azt mutatták, hogy a vizsgált, potenciálisan 
befolyásoló változók számos esetben nem elégítik ki a diszkriminanciaanalízis azon matematikai feltételeit, amelyek mellett a kapott függvények és az azokból levonható következtetések megbízhatók lettek volna. Ezért a kevesebb elemzési feltétel egyidejü fennállását igénylő logisztikus regressziófüggvény alkalmazása mellett döntöttünk.

A függő változó alapján három csoport azonosítható: akik nem készülnek külföldre, akik tervezik a kiutazást (az ő esetükben kevésbé határozott a szándék) és akik külföldre készülnek (határozott szándék vagy folyamatban levő kiutazási előkészület). Az előzetes vizsgálatok alapján arra a következtetésre jutottunk, hogy a határozott és a kevésbé határozott kiutazási szándékkal rendelkezők között is jelentős különbségek tapasztalhatók. Azonban ezek a különbségek nem vagy sokkal nehezebben kerülnek a felszínre abban az esetben, ha a kiutazni nem szándékozókkal vetjük össze őket. Ezért a további elemzéseket több szakaszra bontottuk. Az első szakaszban nem vizsgáltuk a kiutazási szándék határozottságát, hanem a kérdésre adott válaszokat bináris változóvá transzformáltuk, szem előtt tartva azt, hogy szóba jöhet-e a válaszadó esetében a kiutazás. Majd a kutatás későbbi szakaszában állapítjuk meg a kimutatható és látens különbségeket a határozott és a „csak tervezgeto" potenciális kivándorlók között.

A bináris logisztikus regressziószámítás célja, hogy a függő változók megbízható lineáris kombinációja alapján meghatározzuk a kiutazási szándék esélyhányadosát, nevesítve azt, hogy mekkora a kiutazási szándék meglétének és hiányának (az itthon maradásnak) bekövetkezési valószínűségeinek egymáshoz viszonyított aránya (Hajdu 2003). Alapmodellünkben a kiutazási szándék kialakulásának vizsgálatakor - a témával foglalkozó szakirodalmak tapasztalataiból, hipotéziseiből kiindulva (Becsei 2004; Blaskó, Gödri 2015; Dabasi, Réthi, Horváth. 2016; Molnár et al. 2015; Nyírő 2013; Szeitl 2015) - az emberek nemét, életkorát, nyelvtudását és boldogságérzetét vettük figyelembe. (Az adatbázisban szereplő további változók vagy nem gyakoroltak szignifikáns hatást az eredményre, vagy nem javították érdemben a modell magyarázó erejét, előrejelző képességét, így ezeket kiszűrtük az elemzésből.)

\section{A bináris logisztikus regresszióelemzés eredményei}

A meghatározott bináris logisztikus regressziófüggvény paramétereinek értelmezésével választ kapunk arra, hogy az alkalmazott magyarázó változók milyen mértékben képesek befolyásolni a kiutazási szándék valószínűségét. A kialakított alapmodell előrejelzési pontossága $74 \%$, pszeudo $\mathrm{R}^{2}$-értéke: 0,326, további paraméterei a 3. táblázatban találhatók.

Eszerint vannak „pozitív” és „negatív” befolyásoló tényezők (lásd a regressziós együtthatókat tartalmazó oszlop értékeinek előjeleit). Pozitív befolyá- 
3. táblázat: A bináris logisztikus regresszió eredményei Outputs of the binary logistic regression

\begin{tabular}{|c|c|c|c|c|c|c|c|c|}
\hline \multirow[t]{2}{*}{ Változók } & \multirow[t]{2}{*}{ Együttható } & \multirow[t]{2}{*}{$\begin{array}{c}\text { Standard } \\
\text { hiba }\end{array}$} & \multirow[t]{2}{*}{$\begin{array}{c}\text { Wald- } \\
\text { statisztika }\end{array}$} & \multirow{2}{*}{\multicolumn{3}{|c|}{$d_{f}$ Szignifikancia Esélyhányados }} & \multicolumn{2}{|c|}{$\begin{array}{c}95 \% \text {-os } \\
\text { konfidenciaintervallum }\end{array}$} \\
\hline & & & & & & & alsó & felsö \\
\hline Nem & 0,200 & 0,065 & 9,521 & 1 & 0,002 & 1,221 & 1,076 & 1,387 \\
\hline Életkor & $-0,080$ & 0,004 & 494,350 & 1 & 0,000 & 0,923 & 0,917 & 0,930 \\
\hline $\begin{array}{l}\text { Legmagasabb } \\
\text { iskolai } \\
\text { végzettség }\end{array}$ & $-0,110$ & 0,027 & 16,365 & 1 & 0,000 & 0,896 & 0,849 & 0,945 \\
\hline $\begin{array}{l}\text { Beszélt idegen } \\
\text { nyelvek száma }\end{array}$ & 0,385 & 0,047 & 68,441 & 1 & 0,000 & 1,469 & 1,341 & 1,610 \\
\hline Boldogságérzet & $-0,440$ & 0,017 & 666,870 & 1 & 0,000 & 0,644 & 0,623 & 0,666 \\
\hline Konstans & 4,635 & 0,188 & 607,182 & 1 & 0,000 & 102,987 & - & - \\
\hline
\end{tabular}

soló tényezőn azt értjük, ha a magyarázó változó növekedésével a kivándorlási szándék esélye növekszik, negatív befolyásoló tényező esetén értelemszerüen ennek az ellenkezője történik. A Wald-féle próba a nullhipotézis tesztelésére alkalmas, vagyis hogy az adott magyarázó változóhoz tartozó regressziós együttható értéke 0-val egyenlö-e. A 3. táblázatban szereplő szignifikanciaszintek alapján megállapítható, hogy a nem, az életkor, az iskolai végzettség, az idegennyelv-tudás és a boldogság szignifikánsan hat a vándorlási hajlandóságra.

Általános demográfiai tapasztalat, hogy a migrációban férfitöbblet mutatkozik, azzal együtt, hogy ennek tendenciájában, intenzitásában lehetnek változások, eltérések. A mintánkból levont következtetések megerősítik ezen ismereteinket, mivel a férfiak esetében a külföldi élet tervezésének esélye átlagosan 22,1\%-kal nagyobb, mint a nők esetében, amennyiben minden egyéb tulajdonságukban hasonlóak lennének a két nem képviselöi.

Az idegennyelv-tudás érthetően nagyobb magabiztosságot nyújt a kivándorló számára. Különösen igaz ez a célországban eltöltött időszak első szakaszában. Sokan azért nem tervezik a külföldi munkavállalást, mert tartanak attól, hogy a nyelvismeret hiánya hátrányos helyzetbe hozhatja őket a külföldi munkavállalás során. Az elemzésbe bevont változókat kiegészítő információk felhasználásával megállapítható, hogy azok számára, akik rendelkeznek a célországban magyarul beszélő ismerőssel, rokonnal (ők egyre nagyobb számban vannak), vagy eleve a külföldön élő ismerős, rokon segíti a migránst a külföldi munkalehetőség megtalálásában, a nyelvismeret hiánya kevésbé gátló tényező. A külföldi segítség megléte és a nyelvismeret közötti szignifikáns kapcsolat is erre utal $(\mathrm{F}=6,58$; szignifikancia $=0,010)$. Számításaink szerint minden egyéb jellemző változatlansága mellett egy-egy újabb elsajátított nyelv átlagosan 46,9\%-kal növeli annak az esélyét, hogy valaki külföldön képzelje el az életét. A negatívan befolyásoló tényezők közé a boldogságérzet, az iskolai végzettség és az életkor változók kerültek. 
Mivel az elemzés keresztmetszeti adatokra épül, lehetőség nyílt az adatbázist több részre bontva, eltérő szempontok szerint vizsgálni, így a modelleket külön-külön is futtattuk minden régióra.

Az iskolai végzettség országos szinten szignifikánsnak bizonyult, regionális szinten viszont a Dél-alföldi, a Dél-dunántúli és az Észak-alföldi régiókban nem mutatott szignifikáns hatást. Az országos mintát tekintve megállapítható, hogy az iskolai végzettség szintjének emelkedésével a kivándorlási szándék esélye csökken. Az iskolai végzettséget egyszerü ordinális skálával kódolva azt láthatjuk, hogy annál az embernél, akinél eggyel magasabb szintű az iskolai végzettség (ceteris paribus), a kivándorlás tervezésének az esélye átlagosan 10,4\%-kal alacsonyabb.

Természetesen az eltérő iskolázottsági szintek között vannak eltérések, ezeknek a feltárására parciális vizsgálatot végeztünk, melyből kiderült, hogy a kivándorlási szándék esélyhányadosa egy érettségivel rendelkező személy esetében 1,45-ször akkora, mint egy egyetemi/főiskolai végzettségünél. Abban az esetben, ha érettségi mellett szakmája is van, az esélyhányados 1,64, a legmagasabbnak tekinthető a szakmunkások értéke, amely 1,82-ször akkora, mint az egyetemi/főiskolai végzettségűeké. Még a legalacsonyabb iskolai végzettség (8 osztály vagy kevesebb) esetében is nagyobb az esélye a kivándorlásnak a felsőfokú végzettségüekhez képest: az esélyhányados 1,22. Természetesen az egyes iskolázottsági szintek az elvándorlási szándék tekintetében nem homogén csoportok. Az egyetemi/főiskolai végzettségűek csoportjában például a pedagógiai, a jogi végzettségűek többnyire az országban maradók közé sorolhatók, az egészségügyi végzettségűek körében pedig az átlagot jóval meghaladóan kívánnak kivándorolni. A szakmával rendelkezők között a vendéglátásban és az építőiparban dolgozók kivándorlási szándéka a legmagasabb.

Szintén jelentős a boldogságérzet hatása a kivándorlás tervezésére. A felmérés során a boldogságérzetet tízfokozatú skálán kellett érzékeltetnie a válaszadóknak, ahol az 1 jelentette a boldogtalan és a 10 a maximálisan boldog állapotot. A logisztikus regressziófüggvény alapján ha valakinek a boldogságérzete egy egységgel magasabb (ceteris paribus), akkor a kivándorlás tervezésének esélye átlagosan 35,6\%-kal alacsonyabb. Természetesen nem mindegy, hogy milyen az az alapállapot, ahonnan a boldogságérzet mondjuk egy egységgel javul. A boldogságérzet javulásának esélyhányadosait két egységenként határoztuk meg: az átlagos boldogságszinthez viszonyítva $(6,24)$ akinek 2 egységgel jobb a boldogságérzete, annak átlagosan 0,43-szor akkora (tehát jóval kisebb) az esélyhányadosa a kiutazás tervezésére.

Az életkor csaknem minden társadalmi jelenséggel összefüggésbe hozható, viszont természeténél fogva más hatást fejt ki a fiatal korcsoportokban, mint az idősebb életszakaszokban. A regressziószámítás során az átlagos életkorból indultunk ki (33,3 év), ahonnan ötévenkénti lépcsőt választva azt tapasztaltuk, hogy a kivándorlás tervezésének az esélyhányadosa 0,688-szoros, vagyis minél idősebb valaki, annál kisebb az esély a kivándorlás tervezésére. Ennek a ten- 
denciája azonban a közeljövőben változhat, különösen akkor, ha a kivándorolt fiatalkorúak külföldön alapítanak családot, és az itthon maradt nyugdíjas korúvá vált szülők kiutaznak a gyermekük után. Ennek nagyon is reális esélye azért állhat fenn, mert a jellemző célországokban a gyermekáldás után hamar visszavárják a dolgozót a munkahelyére, és a gyermek elhelyezése az ellátórendszerben magas költségekkel járhat.

\section{A migrációs profilok meghatározása és jellemzése}

A kutatás második szakaszában az előrejelezhetően kiutazni szándékozókat és az itthon maradókat vizsgálva profilokat képeztünk. A kivándorlást tervezőknek négy, markánsan elkülönülő csoportja becsülhető (vö. 2. ábra):

- A legnagyobb csoport a „röghöz kötöttek” csoportja (53,2\%), amely az ország népességmegtartó ereje szempontjából kifejezetten alacsony arány, tekintve, hogy a megkérdezettek életkora 18-60 év közötti (tehát jellemzően az aktív korú népességbe tartozik). A réteg tagjai jellemzően középkorúak, illetve az idősebb korosztályba tartoznak, átlagéletkoruk a legmagasabb a csoportok között. A csoport neve egyrészt azt tükrözi, hogy határozott itthon maradási szándékuk van, ami élethelyzetükből, demográfiai jellemzőikből előre is jelezhető. Jellemzően nem beszélnek idegen nyelvet, foglalkoztatási arányuk meghaladja az országos átlagot, aki viszont nincs foglalkoztatva, az relatíve hosszú ideje munkanélküli. A nyelvet beszélők magas iskolai végzettséggel rendelkeznek, és ennek megfelelő munkahelyük van. Emellett ebben a csoportban jelentős a mezőgazdaságban foglalkoztatottak aránya is. A területi egyenlőtlenségek leginkább itt érezhetők, ugyanis a „röghöz kötöttek" aránya a legmagasabb a Dél-alföldi régióban, ahol a bruttó hozzáadott értékhez országos szinten a legnagyobb mértékben a mezőgazdaság járul hozzá.

- A „potenciális kivándorlók” a legmagasabb nyelvtudással rendelkező csoport, akiknek az átlagosnál gyengébb a boldogságérzetük. A megkérdezettek legfiatalabb rétegét foglalják magukba, többségük még tanul vagy nemrég fejezte be tanulmányait. Ennek megfelelően iskolai végzettségük jelenlegi szintje alacsonyabb, mint a „röghöz kötötteknek.” Ez alól csak a két déli régió képez kivételt, ahol ennek a csoportnak a legmagasabb az átlagos iskolai végzettsége. Ezzel párhuzamosan a déli megyékben a legkisebb a kivándorolni szándékozók aránya. A megkérdezettek regionális megoszlását tekintve a potenciális kivándorlók az Észak-magyarországi régióban vannak jelen a legnagyobb mértékben, hiszen ott minden harmadik ember tervezi a kivándorlást a felmérés adatai szerint. 
- A „szerencsét próbálók” alkotják a harmadik csoportot, amelybe a megkérdezettek közül 870 ember tartozott. Tervezik a kivándorlást, de adataik elemzése során megállapítható, hogy ha meg is próbálják azt, valószínűsíthetően nem lesz tartós a kint tartózkodásuk. Ugyanis nem beszélnek idegen nyelveket, boldogságérzetük, valamint fizetéssel való megelégedettségük átlag feletti (ez alól csak a Közép-magyarországi régió kivétel). A „szerencsét próbálók” aránya a Dél-dunántúli és az Észak-alföldi régióban haladja meg az országos átlagot. Legtöbb tulajdonságukban a röghöz kötöttekhez hasonló paraméterekkel rendelkeznek. Ezért valószínűsíthető, hogy inkább csak a kalandvágy vagy a kivándorlók létszámának általános növekedési hulláma sodorja magával őket. Ezt a feltételezésünket támasztja alá, hogy a csoport felének arról sincs konkrét elképzelése, hogy milyen célországot választana. Akik rendelkeznek konkrét tervekkel az új hazát illetően, azoknak a jelentős része (a potenciális kivándorlókhoz hasonlóan) elsődlegesen Németországot vagy Ausztriát célozná meg.

- A negyedik csoportba a „lokálpatrióták” tartoznak. Olyan kvalifikált csoportról van szó, amelynek tagjai rendelkeznek megfelelő nyelvi és képzettségbeli adottságokkal is ahhoz, hogy külföldön helytálljanak munkavállalóként. ők mégis inkább az itthon maradást választják, még akkor is, ha nem tartoznak a legboldogabbak közé, vagy éppen tartós munkanélküliséggel küszködnek. A foglalkoztatottak jelentős része a tanult szakmájában helyezkedik el. Nem kerülheti el ugyanakkor a figyelmünket, hogy ebben a csoportban felülreprezentáltak az olyan végzettségüek, akik a szakmájukat külföldön nagy valószínűséggel csak nehezen, átképzések segítségével tudnák művelni (közszférában foglalkoztatottak, jogi végzettségűek, tanárok stb.). A csoport elnevezését az is alátámasztja, hogy ebből a klaszterből az országosnál nagyobb arányt leginkább a kevésbé versenyképes Észak-magyarországi és Észak-alföldi régiókban találhatunk. Arányuk a teljes mintának csupán 10\%-át teszi ki. Elgondolkodtató, hogy ez az arány népességpolitikai szempontból kevésnek, avagy soknak tekinthető-e.

A regionális összehasonlítás összegzéseként elmondható, hogy a legnagyobb röghöz kötő erővel a Dél-alföldi és a Közép-magyarországi régió rendelkezik, hiszen a kivándorolni szándékozók és kalandorok aránya itt a legalacsonyabb. Az országos átlag alatt van viszont az Észak-magyarországi, az Észak-alföldi és a Nyugat-dunántúli régiók népességmegtartó ereje.

A migráció kutatásával foglalkozó szakirodalmak a kivándorlás ok-okozati összefüggéseit számos társadalmi, gazdasági, demográfiai tényező aspektusából vizsgálják, viszont a következtetéseknek legtöbbször a kivándorolt személyekre vonatkozó statisztikai adatgyüjtések képezik az alapját (Hárs 2011). A ténylegesen kivándoroltak és a kivándorlást tervezők összetétele azonban jelentős eltérést mutathat. Így előfordulhat, hogy a kivándorlókról származó információkra 


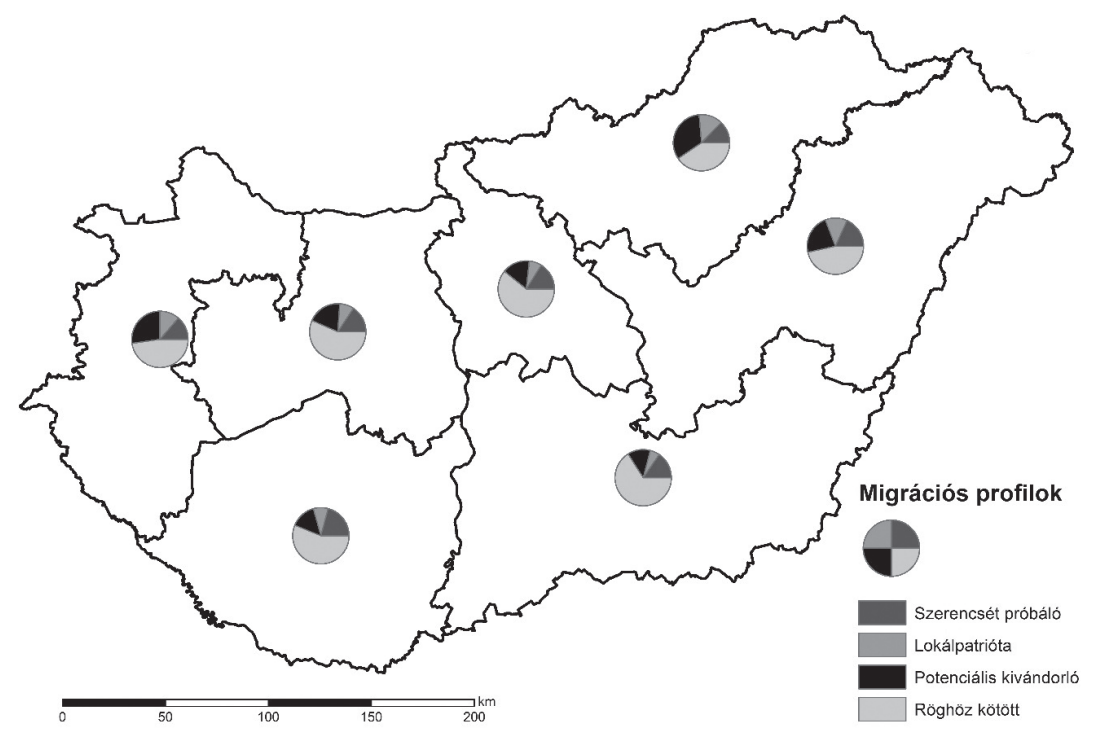

épített tézisek korlátozottan érvényesek a kivándorolni szándékozókra. Ezt mutatják kutatásunk eredményei is (4. táblázat).

Az empirikus kutatás eredményei alapján megállapítható, hogy a korábbi vándorlásoknál tapasztaltakhoz képest még mindig magasabb a férfiak körében a vándorlási kedv, de messze nem olyan markáns a különbség, mint azt a 20. században tapasztaltuk. A vándorlást még mindig inkább a fiatalabb korcsoportok tervezik. A célországok tekintetében napjainkban a nyugat-európai országok vezetnek, Észak-Amerika, Ausztrália már nem tartozik a divatos célterületek közé. A potenciális kivándorlók társadalmi helyzete szinte semmit sem változott a 21. században. Most is leginkább a „külföldképes” szakmával rendelkező egészségügyi dolgozók, mérnökök, informatikusok, szakácsok, felszolgálók, építőipari munkások a mobilak.

A korábbi vándorlásokhoz viszonyított eltérések mellett megállapítható, hogy az egyes profilokba tartozók száma, regionális elhelyezkedése különböző, valamint jellemzőik is szignifikánsan eltérnek egymástól, ezért az egyes profilokban más-más stratégiát célszerű alkalmazni a kivándorlási szándék intenzitásának csökkentése érdekében. Ezeknek a stratégiáknak a kidolgozása nem képezi jelen tanulmány tárgyát, azonban a kutatás eredményei hozzásegíthetik a különböző térségek vagy települések gazdasági, politikai, társadalmi ügyekben döntési helyzetben levő vezetőit ahhoz, hogy a migrációval kapcsolatos helyzetkép egy-egy olyan aspektusát láthassák, amely megkönnyíti a különböző közösségek azonosítását. 
4. táblázat: A profilok kivándorlással kapcsolatos jellemzői Characteristics of migration profiles

\begin{tabular}{|c|c|c|c|c|}
\hline Megnevezés & Röghöz kötöttek & $\begin{array}{l}\text { Potenciális } \\
\text { kivándorlók }\end{array}$ & Szerencsét próbálók & Lokálpatrióták \\
\hline $\begin{array}{l}\text { Jellemző } \\
\text { lakóhely }\end{array}$ & Dél-Alföld & $\begin{array}{l}\text { Észak- } \\
\text { Magyarország }\end{array}$ & $\begin{array}{l}\text { Dél-Dunántúl; } \\
\text { Észak-Alföld }\end{array}$ & $\begin{array}{l}\text { Észak- } \\
\text { Magyarország; } \\
\text { Észak-Alföld }\end{array}$ \\
\hline $\begin{array}{l}\text { Legfontosabb } \\
\text { célországok }\end{array}$ & - & $\begin{array}{l}\text { Az angol } \\
\text { nyelterület } \\
\text { dominál, és csak } \\
\text { utána következik a } \\
\text { német nyelvterület }\end{array}$ & $\begin{array}{l}\text { Az angol nyelterület } \\
\text { dominál, és csak } \\
\text { utána következik a } \\
\text { német nyelvterület }\end{array}$ & - \\
\hline Boldogságérzet & Legboldogabbak & $\begin{array}{l}\text { Legboldogtalanab- } \\
\text { bak }\end{array}$ & Átlag feletti & Átlag alatti \\
\hline $\begin{array}{l}\text { Nem szerinti } \\
\text { összetétel }\end{array}$ & Nőtöbblet & Férfitöbblet & $\begin{array}{l}\text { A nemek aránya } \\
\text { megközelítőleg } \\
\text { kiegyenlített }\end{array}$ & Nőtöbblet \\
\hline $\begin{array}{l}\text { Döntést } \\
\text { befolyásoló } \\
\text { tipikus } \\
\text { tényezők }\end{array}$ & $\begin{array}{l}\text { Mezőgazdaságban } \\
\text { foglalkoztatottak; } \\
\text { nyugdíjasok; } \\
\text { idegennyelv-tudás } \\
\text { hiánya }\end{array}$ & $\begin{array}{l}\text { Jelentős részük } \\
\text { még tanulmányait } \\
\text { folytatja; } \\
\text { idegennyelv- } \\
\text { tudással } \\
\text { rendelkeznek }\end{array}$ & $\begin{array}{l}\text { Kalandvágy; nem } \\
\text { beszélnek idegen } \\
\text { nyelvet }\end{array}$ & $\begin{array}{l}\text { Közszféra } \\
\text { alkalmazottai; } \\
\text { humán } \\
\text { végzettségüek }\end{array}$ \\
\hline $\begin{array}{l}\text { Kor szerinti } \\
\text { összetétel }\end{array}$ & $\begin{array}{l}\text { Közép- vagy idősebb } \\
\text { korúak }\end{array}$ & $\begin{array}{l}\text { Legfiatalabb } \\
\text { csoport }\end{array}$ & Középkorúak & $\begin{array}{l}\text { Fiatal- vagy } \\
\text { középkorúak }\end{array}$ \\
\hline
\end{tabular}

\section{Összefoglalás, következtetések}

A történelem folyamán a vándorlás megpróbáltatásait nagyobb arányban vállalták a férfiak képviselői, mint a nők; az elvándorlók között kisebb arányban vannak a házasok, mint akár a kibocsátó, akár a befogadó népességben. A lakással, vagyonnal rendelkező családok esetében rendkívüli körülményeknek kell bekövetkeznie ahhoz, hogy javaikat hátrahagyva új lakhelyet válasszanak. Ezáltal a migrációs folyamatok jelentősen módosíthatják a nemek és a családi állapot szerinti összetételt is (Hárs 2012; Marien 2015).

A korábbi kutatások eredményei, a magyar statisztikai szolgálat adatai, a nyugat-európai országok tükörstatisztikái, valamint az empirikus kutatásunk adatai alapján egyaránt megállapítható, hogy Magyarország az elmúlt években befogadó országból kibocsátó országgá vált. Az elvándorlás viszont nem egyformán érinti a különböző társadalmi rétegeket. Mivel jóval fiatalabb a magyar emigránsok korszerkezete, mint a hazai népességé, a kivándorlás fokozódása felgyorsíthatja a magyar népesség öregedését és fogyását, valamint ezek területi egyenlőtlenségeit (Kóródi, Siskáné Szilasi 2016). 
A kérdőíves felmérés adatai alapján készített logisztikus regressziós modell segítségével 74\%-os pontossággal előrejelezhető, hogy adott tulajdonságokkal rendelkező lakosok mekkora valószínűséggel tervezik a kivándorlást. Napjaink vándorlásában is a férfiak érintettek inkább, mint a nők, ugyanis a férfiak esetében a külföldi élet tervezésének esélye átlagosan 22\%-kal magasabb a nőkénél. Számításaink szerint egy-egy újabb elsajátított nyelv átlagosan 46,9\%-kal növeli meg annak az esélyét, hogy valaki külföldön képzelje el az életét. A kivándorolni szándékozók és az itthon maradók között tehát markáns szociodemográfiai eltérések mutathatók ki.

A kivándorlási szándék alapján négy migrációs profilt alkottunk: a „röghöz kötöttek”, a „potenciális kivándorlók”, a „szerencsét próbálók” és a „lokálpatrióták" csoportját különböztettük meg. A kivándorlást fontolgató csoportokban a tanulmányaikat még jelenleg is folytató lakosok aránya kiemelkedően magas (40\%), míg az itthon maradók táborát nagyobb arányban képviselik a nyugdíjasok, de regionális különbségek ebben a tekintetben is érzékelhetők.

\section{Köszönetnyilvánítás}

A kutatás az OTKA 109449. számú, Legújabb trendek a magyarországi kivándorlásban című projekt támogatásával készült, a szerzők ezúton is köszönetet mondanak a lehetőségért.

A kutatómunka a Miskolci Egyetem stratégiai kutatási területén működő Fenntartható Természeti Erőforrás Gazdálkodás Kiválósági Központ keretében valósult meg.

A tanulmányban ismertetett kutatás az EFOP-3.6.1-16-2016-00011 jelű „Fiatalodó és Megújuló Egyetem - Innovatív Tudásváros - a Miskolci Egyetem intelligens szakosodást szolgáló intézményi fejlesztése" projekt részeként - a Széchenyi 2020 keretében - az Európai Unió támogatásával, az Európai Szociális Alap társfinanszírozásával valósul meg.

\section{Irodalom}

Becsei J. (2004): Népességföldrajz. Ipszilon Kiadó Kft., Békéscsaba

Blaskó Zs., Gödri I. (2016): A Magyarországról kivándorlók társadalmi és demográfiai összetétele. In: Blaskó Zs., Fazekas K. (szerk.): Munkaerőpiaci tükör 2015. MTA Közgazdaság- és Regionális Tudományi Kutatóközpont, Közgazdaságtudományi Intézet, Budapest, 59-68.

Dabasi-Halász, Zs., Réthi, G., Horváth, K. (2016): Mobility from the pupils' perspective. In: Karlowitz, T. J., Torgyik, J. (eds.): Some issues in pedagogy and methodology. International Research Institute, Komárno, 121-127.

Endrei A. (2004): A magyarországi zsidóság migrációja (1945-1955). Beszélo", 4., 69-78.

Földházi E. (2011): Az osztrák és a német munkaerőpiac megnyitásának várható hatása Magyarország népességének alakulására 2011-2030 között. Demográfia, 4., 213-235.

Gödri I. (2015): Nemzetközi vándorlás. In: Monostori J., Őri P., Spéder Zs. (szerk.): Demográfiai portré 2015. KSH Népességtudományi Kutatóintézet, Budapest, 187-211.

Gödri I., Feleky G. A. (2013): Elvándorló fiatalok? Migrációs tervek a magyarországi 18-40 évesek körében. KorFA Népesedési Hírlevél, 5., 1-4. 
Hajdu O. (2003): Többváltozós statisztikai számítások. KSH, Budapest

Hárs Á. (2011): Magyarok külföldi munkavállalása. Kutatási jelentés. Kopint-TÁRKI Zrt., Budapest

Hárs Á. (2012): Földrajzi mobilitás. In: Fazekas K., Scharle Á. (szerk.): A magyar foglalkoztatáspolitika két évtizede 1990-2010. Budapest Szakpolitikai Elemző Intézet, MTA KRTK Közgazdaságtudományi Intézet, Budapest, 117-139.

Illés S., Hablicsek L. (1996): A külső vándorlások népességi hatásai Magyarországon 1955-1995 között. KSH Népességtudományi Kutatóintézet, Budapest (KSH NKI Kutatási Jelentései; 1996/3.)

Ivanyos, J., Sándorné Kriszt, É. (2017): Measurability of social development: Reflections on applicability of social progress indexes with reference to Brexit. Acta Universitatis Sapientiae European and Regional Studies, 2., 133-152.

Juhász J. (1994): A Magyarországot érintő nemzetközi vándorlás. Demográfia, 1., 33-59.

Kóródi T., Siskáné Szilasi B. (2016): A XXI. századi magyar populáció migrációs szándékának térbeli vizsgálata. In: Berghauer S. (szerk.): Társadalomföldrajzi kihivások és adekvát válaszlehetöségek a XXI. század Kelet-Közép-Európájában. II. Rákóczi Ferenc Kárpátaljai Magyar Főiskola, Beregszász, 134-141.

KSH (1957): A KSH Jelentése: Az illegálisan külföldre távozott személyek föbb adatai. Központi Statisztikai Hivatal, Budapest

KSH (2011): Századok statisztikája. Statisztikai érdekességek a magyar történelemból. Központi Statisztikai Hivatal, Budapest

Marien A. (2015): A területi identitás magatartási megnyilvánulásai, különös tekintettel a költözési szándékra és annak magyarázatára. Észak-magyarországi Stratégiai Füzetek, 1., 4-16.

Molnár J., Gál-Szabó L., Siskáné Szilasi B., Mohos M., Dudás G., Vadnai P. (2015): Legújabb trendek a magyarországi kivándorlásban. Észak-magyarországi Stratégiai Füzetek 1., 28-38.

Nyírő Zs. (2013): A migrációs potenciál alakulása Magyarországon. Magyar Tudomány, 3., 281-286.

Sándorné Kriszt É. (1997): Többváltozós korreláció- és regressziószámítás. In: Sándorné Kriszt É., Varga E., Veitzné Kenyeres E., Korpás A.-né (szerk.): Általános statisztika II. Nemzeti Tankönyvkiadó, Budapest, 203-241.

Sik E., Szeitl B. (2016): Migrációs szándékok a mai Magyarországon. In: Blaskó Zs., Fazekas K. (szerk.): Munkaerőpiaci tükör 2015. MTA Közgazdaság- és Regionális Tudományi Kutatóközpont, Közgazdaságtudományi Intézet, Budapest, 54-59.

Szeitl B. (2015): Helyzetkép a mai magyarországi migrációs folyamatokról. Forrás, 7., 214-224.

Valuch T. (2005): Magyar társadalomtörténeti olvasókönyv 1944-tól napjainkig. Osiris Kiadó. Budapest 